\title{
A Courtship Imagery with the Masculine in Mamluk Poetry, Ibn Al - Naqeeb Al - Fakisi (687) as a Model
}

\author{
Dr. Ali Sahib Issa \\ Department Arabic Language, College Basic Education, University Misan, Iraq \\ Email: aaalqw332@gmail.com
}

\begin{abstract}
Spinning in language: Spinning: A woman spins cotton, linen and other things, she spins it with spinning, and a woman spins. And spinning also: spun. And ghazal: that which is spun is masculine, and plural is a yarn. And ghazal: the hadith of boys and girls. Ibn Sidah: Spinning, having fun with women, as well as flirting.
\end{abstract}

Article Received: 18 October 2020, Revised: 3 November 2020, Accepted: 24 December 2020

\section{The first pattern: spinning in language and convention:}

\section{First resource}

Spinning in language: Spinning: A woman spins cotton, linen and other things, she spins it with spinning, and a woman spins. And spinning also: spun. And ghazal: that which is spun is masculine, and plural is a yarn. And ghazal: the hadith of boys and girls. Ibn Sidah: Spinning, having fun with women, as well as flirting. He said:

\section{Infected Hebrew says its analysis}

\section{Who was the owner of a spindle in sheep?}

And he flirts with them: he talks to them and he flirts with them, he flirts with her, he flirts with her: he acts on this. And in the parable: $\mathrm{He}$ is weaker than the mighty man. And the Arabs say: He flirted with fever; they want an end to get accustomed to an anomaly and repeated it so that she fell in love with her while he was stirred by it (1). Thread: (Ghazala) wool or cotton: d e khitan on the spindle. Ghazal: Fun with Women (2)

Ghazal - flirting with women: Their corruption, he added. He was flirting with the woman: her accident and her wrath. It is said: Spinning the forty, meaning he came down from it, then it is said: He was courting the desire to live That is, he lives comfortably. Yarn flan: the cost of yarn. Flirting with People: Villander some others. AlGhazal: They are having fun with women. Flirting: He who flirts with women is weak in Sa'y (3).

\section{The second resource}

Flirting idiomatically: Connecting the literary arts to the lives of men and women. One of the most famous, famous and enjoyable arts; because women are half men and lead a full life. A woman is a source of contentment, anger, joy, and sadness, which certainly inspires him. The Arab women poet revolves around "Al-Fatiha" and expressed praise and enthusiasm, singling out her poems and stories (4)Spinning is one of the oldest and most famous arts of Arabic poetry. Because it is related to the nature of man and his personal experiences in particular, and love moves all hearts. Poets alone depict this love with sincere affection, as it flows through their tongues with a gentle conscience, to express what is boiling in the poet's mind and what is in his heart (5)From that, then spinning; It is to talk about the beauty of women and praise her for her modesty and charm, 
and basically $\mathrm{u}$ show the spinning with the letter tenderness and sweetness (6)This art is in a variety of forms. And it all leads me to one. Insisting on our neighborhood that confines the beauty of women, from a beautiful woman in the body, to a $\mathrm{G}$ in it in the heart, or dealing with the pain felt by the abandoned lover and the compressed paper that is boiling in his heart, fidgeting, a display of anxiety and despair, or full of hope every encounter And to meet Welch ML (7)Spinning colors, including chaste love, true love and imagination. They view flirting in terms of reality and morality. But love still haunts his human society, as he sees weakness in the scandal of love and in the scandal of the lover; Because love is the mockery and joy of life, and the books of spin are many, telling news of those who are afflicted with love, and those who are lost in the deserts of spinning (8) It is important to say that the spinning stream remained sharp in the Abbasid era, as poets and slave-herders spoke with it, adding in it many ideas and meanings, and it seems to man as if all the poetry systems of the valleys are in them (9)He has more than the poets, and he often organizes it mixed with the complaint of the guide and repels existence, and notes that he was with the masculine, and perhaps imitates and mimics that $\mathrm{X}$ insect, and perhaps the spinning with the masculine issued by a desire of him is the correct one. Al-Shuaraa has independent extensions or syllables (10).

\section{The second pattern: spinning with the masculine, its origin and causes}

Spinning is an unacceptable subjective sound to the general public, e-recovery audiences of men and young men. Of great love $t$ touching. It is very ancient and known to the people of the earth despite the human aversion to it. Some books mentioned him with contempt. There were few verses about al-Ghazal or masculine in the preIslamic era (11)The Islamic culture has been stripped of young people in a solution that dazzles the viewers present in the majlis, enchants their children, and won them the knowledge that won sweetness from the logic and sophistication of minds Tzipi, stirred the aqrai. The poets described the beauty of their servants, and they expressed their astonishment at what they saw of the beauty of their masterpieces that the culture gave them, and here they revealed their longing and longing for the children they loved (12)The purpose of spinning with the masculine was common in the Abbasid era, especially in the era of the genius of Abu Nawas (d.198 AH), but its inception preceded this era. Several factors were combined in the Umayyad era from its appearance, which are: The most important of which is the penetration of the elements of the Persian and Roman civilizations in the Umayyad state. It entered where the waves of loyalists and concubines entered, and this wave was accompanied by abundant funds from the Islamic conquests, which created the emergence of the Tarab councils that need a new type of poetry, to express this sinful life that urges the owners of the paper to their taste, reinforced the emergence of the trend of newborns bin Yazid bin Abd al-Malik (d.126 AH) to the caliphate, who lived for the sake of pleasure, and was not merry, then drinking wine only and listening to singing (13). The famous Anadamah poets were on the boards of deception and then such as al-Mashagheb ibn Ils (d.169 AH) and Hammad Ghird (13). T. $161 \mathrm{AH}$ ) who accompanied him until his death (14)We are dating, in this era, great fun and spinning, which has a multiplying effect of religion in Alan Foss, and people are heaped on life in the economy, and the spread of immorality between the public, the private and $\mathrm{E}$, as well as the spinning exceeded the limits of Arab traditions, and drowned in obscenity to some extent Walsh Dawes Ugly (15)This means that this phenomenon has spread in Islamic societies since the middle of the second century $\mathrm{AH}$ (16)But some poets admired the masculine humor and affection, so the masculine does not exist at all. In fact, some of the owners of this gazelle were scholars and jurists, but they kept up with the traditions of the era (17)In addition, there were poets who went crazy (and immoral; it is humor and lack of modesty), 
engulfed in a stream that flows with the rest of the people to the point of obscenity and excessive pornography. Increasing gears and dislocating the scourge of the DONC scourge of attachment to the men, it was friendship for young people and their cause was suspended, influential, inspired many thieves and walsh a carriage, this is the caliph (the secretary) (v $198 \mathrm{AH}$ ), he sent money to the servants, his mother (Zubaida) virgins in the simplest clothes of children, and showed them to them Garytan (18)Therefore, we go with the characteristics that distinguish from ancient Arabic poetry that flirt with the masculine, and one of the most important reasons for this, if not the most important, is the spread of homosexuality in Arab society in the later eras (19).It is noticed that anomalies are prevalent in many human civilizations throughout history. For example, in the ancient Egyptian civilization, until I reached $n$. The ancient Egyptians attributed anomalies to some of their gods, that is, they sanctified it and gave it to the divine PGH. We observe this in Greek civilization, so that the Greeks did not just forgive the deviation. Rather, they respected and respected her, and made a man's love for a man the ideal love, and placed him in a higher position than a man's love for women, and considered this a natural love without privilege, and that is why this type of love was called (Greek love) (20)Plagued by tuberculosis itself, which is what we have seen in many other civilizations in the Islamic civilization, when it has reached maturity and begins to address moral degeneration; Instead, they may have had a combined cause for moral breakdown, which was not the combined cause of other civilizations. Among the most important of these reasons is the mixing of a large number of different human races with each other, with great differences in religions, beliefs, customs, traditions and ethical standards (21)

It cannot be denied that there are multiple reasons for the spread of spinning with the masculine among the poets. But we cannot deny the effect of homosexuality on it, as this deviation spread among people, and its effect must appear in the hair of one of the faces. Hence, the poet who flirts with the masculine is not required to be afflicted with homosexuality, but the spread of sodomy among people may lead them to prefer courting the masculine and encouraging poets to organize in it. This means that the spread of deviation creates an atmosphere that encourages flirtation with the masculine, and the poet is forced to keep pace with this atmosphere a little or a lot, if he wants to spread his poetry and his popularity (22)Among the reasons for the spread of this phenomenon are the large number of female slaves, the spread of immorality and immorality among them, which led to asceticism among women, and the attempt to seize pleasure in another way, in addition to drinking gatherings, and what was in them of the bartenders on the part of beauty and immorality (23)And from that was the impact of the Islamic conquests, the presence of thousands of female slaves of different races, colors, destinies and prices, and as a result the enjoyment of women became easy and affordable for many men, so they began to touch other ways. To vent their love and the love, pride and dignity that accompanies them, and a sense of harmony and affection between the two lovers, so look for it in the love of the children, and this coincided with the presence of the Persian and Roman men. The navigator of faces, white-fleshed, thinskinned, refined them from their ancient civilization, and acquired the arts of tenderness and circumstance close to the Bedouin desert (24).Critics and researchers differed regarding the reasons for the spread of the phenomenon of flirtation with the masculine in Arabic poetry in general, some attributed it to the mixing of Arabs with other nations (25), and some attributed this to the tradition of the poets who said about this purpose (26)And no matter how aggravated the matter by this phenomenon, and it dominated its growth and reproduction, and there were factors that nourished it and gave it life, Dr. Muhammad Zaghloul Al-Salam said in his discussion of the spinning of the masculine in the Ayyubids: Of the Turkish children from parts of Asia, and they became like they are relatives of people, so that 
the princes and sultans; but scholars and scholars have a passion for religion and piety accompanies the youth of morning faces in their gatherings, and they did not see a defect or mistake in this regard for one of them with one or two of them To accompany him in his privacy in their use of food and medicine "(27).

\section{Type III: Image of spinning Palmzkr in}

\section{Walsh Presentation of the Mamluk}

Spinning a lot in the Abbasid era was very frequent, and it could even be said that all poets meant regimes that were interested in the accusation to flourish on a large scale; The most skilled poets used it, and crafted it with their modern fertile mentalities, and what they had from generating old meanings, and inventing many new ideas and conceptions (28)There is no doubt that alcohol addiction at that time led to a lot of obscenity, tampering and pornography, for society was full of atheists and heretics, and people of various religions Magi and Magi, and here many went to unleash themselves committing sins, freed from every law in creation, custom and religion. 29)It seems that what made it easy to fall into this sin was the large number of intersex boys brought in from nations, where such sin was common (30)Under these circumstances, Ghazal's poetry blossomed with masculinity, and spread until it reached its climax by Abu Nawas, in whom much of his artistic energies were used (31)When his poetry came in fiery passion, it reached the top in performance, and the sweetness of harmony, despite the perversion and extremism, and the excess resulting from the abnormal nature of Abu Nawas, he loved a number of children (32)

B - Dinar is the spinning with the masculine, dealing with depicting the boy in his organs, as the woman depicts in her case, her waist and cheek, and completes her eyes with her hair and folds and even in her singing and mediating, and pictures of poets being, and Wanderer, watching and catching up, like SOW Rhea Mutaimon in love with women, fascinated by his appearance
The beauty, its narration, the charm of his head and his smile, and the man is fascinated by the beautiful and charming woman. They flirt with the masculine. But they did not descend to the obscene meanings that we find in Abu Nawas, Abu Al-Hassan Al-Salami, Ibn Hajjaj and others (33)This proves that the image of the boy between the behavior and behavior of males and females in the university and how her body seduces men, so the initiation of the third gender does not mention her is not a female, for their love reached the point of interaction with what they do (34)This phenomenon has become a prevalent feature in this era (Mamluk). Poets also narrated those poems that were told in the Abbasid era.There are scholars who went on to say that most of these poems that were said about courting children are nothing but imitations of what was said previously, as the decline of the role of women in this era led to their failure. Declaration of love relationships between poets and their loved ones, in contrast to what is found in the Arab heritage. The emotional relations of some poets, so spinning with the masculine is a cover for emotional relations with women, or in line with public taste, which facilitated the spinning with boys (35). This view appears to be fraught with weakness and scientific evidence.

Some researchers and scholars, to justify this phenomenon among the poets of the Mamluk era, go to:

Many of them weaved with boys to keep pace with the poets of the Abbasid era, and imitated them in order to show their ability to walsh kart, and to enable them to perform all the traditional arts of Walsh (36). Of course, this opinion also lacks scientific evidence. It is important to say that the poets of the Mamluk era did not invent the poets of the Mamluk era, as we mentioned above, the proportion of historians of Abu Nawas or Jarrah of the poets of wine and mixing in the Abbasids who responded to the civilizational and cultural openness. Experienced by their community, and who expressed their admiration for a foreign woman who resembles young men in 
her share in the fully covered market, and who flirted by including spooked by Arab women, such as the boys who flirted with them (37)It should be noted here that the poetry of alGhammana during the Mamluk era was recorded as a qualitative leap in the field of spinning art. The poets said from the experience of the owners of obscenity and pornography, who grew up among populist societies in the late Abbasid state, and worked to develop them, which made the Ghulamani office expand a large number of poets, after they were in previous eras representing a small and unnatural group (38)What attracts the attention of the student of al-Ghazl in this Mamluk era is the frequent return of the pronoun to the masculine. It is true that poets in the Abbasid era mean their true stubborn conscience, just as they mean true femininity. But many indications in spinning these compressors with proprietors indicate that what is meant by a real masculine (39)This, the poetry of the Ghumana was an inscribed color of poetry, and it is not justified by artistic, Arab and moral norms in previous eras, but in the Mamluk era, tomorrow of the year was a call, and we missed it and made it one of their objects and walsh a vehicle. Which he says about what the poet talked about in the late Abbasid era, and in the late ages of countries and Emirates (40)It is noted that the deer appears manly in Mamluk poetry. We also found in most of the poets that they were traveling slaves, the names of the children in their spin, the tradition of the hadiths and the Mestizo poets, this is the son of the poet Kitab Khoan (d.665 AH), one of the poets of the sixth century, a book of poems of great systems, weaving a thousand boys, and called it (boys). Also known as Ibn Munir alTrabelsi (d.548 AH), he was a follower of Mules, known as (Ibn al-Afrit), and he was fond of Meluk in his name (Tatr) (41). He frequently flirted with the masculine in the Mamluk era, and Ibn alHamwi (d.837 AH) was often martyred. In his book (The Treasury of the Literature and the Very Warrior) as evidence for that, a number of poets participated in it (42)Of course, the courtship with boys increased during the Mamluk era, and he did not hesitate to mention the virtues of the age from the jurists and judges, as if the matter had become normal, and there is no blame on him, and some poets. Before the Mamluk period he was preoccupied with it, and it is rare in the Mamluk era that we find a poet who did not say few or many children. It seems that this spindle was not apparent to some poets. Because it is customary for the female to address the masculine speech of love and illusion, or to promote her poetry after the poets found the turnout of people like this show Walsh (43).If courtship with ginseng was a manifestation that flourished in the Mamluk era, this phenomenon now embodies immorality and its position as moral decay, and in this era. The boys are full of pictures, bars, moneylenders, and entertainment clubs, and poets have begun the era of crowding, and I wanted to broadcast their salvation, and I took pictures of their chests and painted the features of their weaving, and in the poems, impudent housewives. He did not want to, and did not hesitate to use obscene and obscene language (44)It is known that the tributaries that fueled this phenomenon in the Mamluk era reached its climax, there are slave markets in which he disposes of the races and ethnicities of children every day, and there are prisoners of war, and there are expatriate sects, such as: Al-Awirat, that Tatar sect that came to Egypt during the era of (Katboja) and it was It is inhabited by (Husseiniya), and its youth knew camels until it was said: the full moon so and so. Full moon so and so (45)It should be noted that the increase in cross-spinning coincided with the mixing of wealthy non-Arabs, and the abundance of Turkish and Roman slaves of Dilmun. That is why poets of the Mamluk era spread in the acids of immorality, purity and aggression in their poetry, so they began to compete in the red nights of males, and spend with their maternal men. This phenomenon is all strata of society (46)Mamluk poets organized many poems and songs to flirt with men and their beauty, which were collected by insane writers and scholars of piety, so the courtship of the masculine was apparent to the public at that time and was not limited to the 
category of poets. Without others and it is clear from the sayings of historians and writers that there is a peculiarity in that school. The topic concerns a number of writers, who are in three teams: the party team, pornography and immorality, and one expressing true love. For the boys, the third team wanted to compete, innovate, and innovate (47)Among the other signs I am the Mamluk poets "in drawing a scandalous image, and they reached their audacity to some rudeness in describing the physical positives of youth, and the factors of attraction and their effect on them, and the change in quote from him and hide ... so they said to him in the uncle and the holy water and the princes have beards and eyelids and eyes On the head ... what the woman did not say "(48)This indicates the progress that young people say in becoming a hymn to the poets of the Mamluk era, which is almost devoid of the poet and the writer of letters to say on this subject (49).

\section{The fourth style: the image of spinning with the masculine in the poet}

\section{The first paragraph: lighting in the life of Ibn Allen Luqaib poverty Lissy}

He is Nasir al-Din, Hassan bin Shawar, and bin Tarkhan bin Hassan al-Kinani, and his surname is: Abu Muhammad, Abu Ali, and Abu Nasr (50). It is known as Thousand Lyse. They said about him: Among them is Sheikh Atheer al-Din Abu Hayyan: I sat with him in Cairo repeatedly, wrote about him, and he was well organized, and he died in the year eighty-seven and six hundred (51)The poet's book called "Houses of Love and Homes of Understanding" mentioned the conflict that took place between the writers of his time and between him, and it is in two volumes, and it has a saving treasury in two volumes, the best torment. Harmonious and his poetry in which the strong and elegant pun, one of those knights insisted on the essence of who was among the poets of Egypt at that time, and his verses were good until the end (52). It seems that his verses differ from his poems (53)Hassan bin Shawar, nicknamed (Ibn Alan Laqeeb), is considered in the open air of the prominent seventh century $\mathrm{AH}$. He was known for his boycott and Toriyati. They were organized in various purposes and occasions, and it is noticed that his great divan did not reach us, and some of the translation had seen his plan and took a son from him Fadlallah Al-Sen (d.749 AH), health scholars (d.764 AH), and Ibn Shakir comic book B (d.764 AH) (54)This poet raised Fustat and lived, and the two phenomena of the Ayyubids of the Mamluks witnessed the two phenomena of communication, Baybars (d. $676 \mathrm{AH}$ ) and Sultan Qalawun (d. $689 \mathrm{AH}$ ) in Egypt, so he went to Hama, and he called Dhahabi (d. 748 AH) the title (Soldier), which means That one of you in the military air, as well as these data, bless many of the personalities of his time, including poets, dignitaries and ministers, and the Sunnis of the people praised some of them, and there were between him and them inward poems and mocked others (55)His son Yaghri Al-Bardi (d.874 AH) said in his book distinguished by the sign (Alan Jum in the depths of the kings of Egypt and Cairo): "He was and so are the literati." (56)He died on Sunday night in the middle of March, and he buried the leg of Al-Muqattam, who was seventy-nine years old, in the year of eighty-seven - six hundred, and between him and the nation of knowledge was Shihab al-Din Mahmoud alHalabi (d. 725 AH) company, babysitting, and study in the declaration of the loan (57).

\section{A second paragraph: Walsh Pay spinning Palmzkr}

This color of spin increased in the sixth and seventh centuries $\mathrm{AH}$, so poets accepted to describe children with their beauty, and we do not exaggerate if we say: the balance of women recedes, if it is measured by what the book seduced. Through male beauty, it is rare to find a poet who did not speak his way in this field (58)It is desirable that spinning with boys is nothing more than an imitation. It is a natural consequence of a bad moral and social situation. As a result of the civilizational deterioration of the Arab country, in the anomalous wave the inhabitants of 
Lok Ghazaleh deviated from the era of Bani Abbas I, which had clear and influential repercussions for the saint presenting this period (59)I was drawn in this until the opinion of some scholars of the era who had a good selling reputation, had a long and prestigious position, and assumed official powers for religion and religion. The tendency towards youth was among the habit of the kings of that time (60)And it seems that the matter was not limited to the general public. Indeed, many of the children of the upper class, their honorable family, and those who had a high position among them, came to the children because of immorality and immorality, underestimating values and morals, and violating the sanctity of religion. Strongly present (61)The poet and his son Alan Lqeeb were among the first poets who fought in this art, so he wrote to him what they suffered and what they opposed, or wanted in terms of the prevailing poetic taste. He had a clear emotional experience. But it is a sincere emotional experience, with which I talked about friendship and young people learned from them. This inspired him much of his pedophile poetry (62)It is important to say that the friendship and education of young people whose subject

That he came from the monastery of Shaaran.

You have grown up, ants, or have become Sulaymani ${ }^{(65)}$

Most of the Mamluk poets described the boy's appearance and appearance, leaving nothing but his description. They described the excuses, the redness of the cheeks, the glow of the gap, the

In the two pages of his cheeks is a pain for the mother so I marvel at the ace of his excuse the growth of the mother ${ }^{(66)}$

Lacey stands a thousand seconds when he calls her a beautiful boy (Fatah) and he loves her to sip matter is Matt $\mathrm{Rh}$, has inspired many of the Walsh Cart texts, regardless of the depth of the artistic level, or the beauty of the style and the social degradation of its place (63)So Har bin Alan to the poor Qeebeeb is not, because I am in this love. He was expressing a psychological tendency represented in his love for children, and the expression of this poetic love.Accordingly, the images of the poet al-Ghazl are most of them in the memorial, which is a combination of what I noticed of humiliation or obscenity, which spread before that because of the capture of the wars of the slaves of the Crusaders, and what the slave traders did, add to the weakness of faith, so there is no difference between $\mathrm{M}$ is a peace, or from a Christian monastery Haran Giza (64)The poet Alan bin Laqeeb walked in this direction - flirting with the masculine - and his words were overpowered by tenderness, softness and clarity, m spun with a Christian boy who came from the Haran monastery in Giza, the most beautiful meanings and the most accurate qualities And he sang by mentioning the sensual qualities, and touching in the yarn to describe the matter, and he says: [simple]

\section{I asked a monk for his cheek, and he told me and he \\ became bored with his excuses, so I said to him}

beauty of the two friends, and the notes. The poet mastered the description of excuses from his saying: [From Al-Kamil].

\section{And I hid his love until he started to deceive, and the greatness of his excuse slept on me} cheek. Here, our poet paints a spinning painting, 
so whoever wants to heal must drink from saliva (Fatah). Because his saliva is a cure and a cure for every injured and sick person, as for the smell of that boy, it is similar to the smell of the myrtle

\author{
And healing in a sip of Alberh him \\ in Ahh cheek e A to open the ${ }^{(67)}$
}

This is ,and was the son of Alan Luqaib in the texts of the spinning Alglmana, combines the originality of the poet and the sincerity of his feelings on the one hand, the traditional method, on the other hand,

a photographer

\section{And that my heart and he does not lie with all tired of me and writes ${ }^{(68)}$}

That is why the poets defended Latvinon from broadcasting their salvation, photographing boxes, and drawing features of their mahawki, and Fang Klmanm, who was the one who escaped from their feet, in the paths of obscenity, and they said that, and they did not hesitate (69). For the poet, the matter did not stop at the limits of sensory

Whatever is hidden from you more ,your heart is telling( ${ }^{70}$ )

The poet became ill with this separation, and there was nothing in front of him but beautiful memories echoing in his mind and twang in front of him, depicting the abandonment of loved ones, and the anguish of love and exaggeration, and longing for loved ones, while depicting the pain of

Drra organized their contracts from Odmaa my heart and my skin is not Sabri with me I

left my institute Kalplqa features a good life in bagasse not Ttmaa due Ohbabi who were with me tree that has perennial greenery and white leaves, so this smell and the cheeks of that boy is the source of his refreshment and the recovery of others, in his saying: [From the theater]

\author{
Ribat (Fatah) heals the sick with it, and the \\ smell of myrtle of excuses revives me
}

and for p e Palmzkr, tightening its Hyamh, and incidence in the nets love the boy, Indicating the sincerity of his affection, by saying (From the rapid)

\author{
I love as my witness \\ and you - O inhabitant - World
}

photography; but in the picture, the real pain describes the burning and parting pain in the chest, then longing, and the contents of the parthenogenesis yarn, such as granulation and longing, with some sensual signs. He says: [From the uprooted]

\section{My longing for you is great, and your heart entertained him}

separation and being away from loved ones, especially the pain that comes within moments Farewell and parting; So the poet and his beloved have shared the pain of separation and Charaka in shedding tears, what happened to them from the impact of Alp J n ,saying(full)

\section{Albin good day reduced depositors and end their Almti XI did not see the farewell of interest and then sigh Antnat $O$ soul was dead on their passing crying to the moon reunion because Balojra}


and hurt was the fire of sorrow in my ribs

fled to disperse what remains of Mdmaa perished from Shawky and Hyper Todjaa ${ }^{(71)}$ has Admt patience on Vrackm

O displaced Will you return

if not accustomed to the lands

of water encourages wa

In this regard ,says: (of Mdzu Waller ml)

After you is the difficulty of the paths ,nor the fire of the owner raising the servant with that ${ }^{72}$ )
I walked longing in my heart, and my heart threw a light on.

These are some of $\mathrm{my}$ characteristics.

He also has (From Al-Sariqi)

\section{Carry over the ring and} girdle, scrunch for my extremity and for my tears $^{(73)}$
Do not ask about the state of my longing, and

if there is a carrier between them
It seems that the phenomenon of young boys' adoration, loyalty to them, singing about their beauty, and their fascination with their magic, has become, in this era, an overwhelming social tone, which paints us a picture of a society with orientations. And stages and habits (74). In his spin, the poet addressed the male, picturing one of

For he who is humiliated by beauty prevail

if Thy long-awaited adversary rises $^{(75)}$ the children, and contained all the qualities of beauty, but the poet's words to the male hid behind him meanings and descriptions indicating the masculine and the feminine share these characteristics. Beauty is the raw material for his poems, from his saying: [From the forum]

Will you not, $O$ Prince of the Navigators, cease and you will never be separated from a little

And for her beautiful pieces, Sowr, where the apartment is located, and Hiyam H. And the lips of blackness that serve as a witness, cold water or fight, saying: [Medzo and Waller Mill

\author{
Fawn looked Musannaf \\ that cod Almhvhv \\ and $\mathrm{mAh}$ Li tit, \\ a Shohdi sprayer $\mathbf{P}^{(76)}$
}

\author{
If only the mother and violence \\ saw good commends the \\ moon $x d$ uh pink \\ it pink $x$ d a
}

It is noted that the meanings of spinning with boys do not differ from the meanings of spinning with women. Rather, the matter is sometimes confused, if there is no evidence to show that the one who is 
flirting with him is a boy or a girl. Because they described strength, agility and footage. In A Thousand Lycian Baggulam, another Meleh might love him and be patient with the fine; But this salih is a stalking poet, with PKT eyes, whistling about the informers, who got what he wanted, and

\section{It is a}

scorpion from its temples, so from your gardens are the eyes of your waters, and we do not know to whom we will suspect your lives?

And no one has proven to him your steadfastness, and only he who lives will revive you $^{(77)}$ ?

In the image of Ghazala, no less than her predecessor, Ibn Al-Aan pictures of Qeeb Jamal the boy in terms of shape and body. He was standing at (a local loophole) and (a resource cheek) and the image of the employee (Al-

Then he turned to his cheek that was supplied by the Originator of creation, and he was alone, and that is narrated from the coolant ${ }^{(80)}$

In the same context, describes the poet and his beloved sensory description of ,by not hide his passion and his declaration of falling in love ,

The gap Hababha Intat Alochenb you FT blood hearts tinged ${ }^{81}$ )

It is important to say that most of the images in the poems spinning with the masculine state a description of the boy in terms of shape and body. Etc. (82). And he also has in the masculine,

\section{T. Allen Hama abstainer Uah the above gap Kaloqahi ${ }^{83}$ )}

here the poet reveals his desire to ask this boy, and sang the charms of visualization He had a degree of beauty, from the redness of the cheeks, the sweetness of speech, the beauty of the eyes, and he sipped his nectar, saying: [From abundance]

O the sweetness of the cheeks, your protection is from me, and you the wine of the ribs, and how much we must, and you love the seafarer to oppression? $O$ my heart, stand steadfast in idolatry, for your lightning in my hand is sufficient for you to suffer

Waqidi) and (Al-Mabarad), this is Al-Waqidi (d.207 AH) to preserve the hadith (78) and this file (d. $286 \mathrm{AH})$ for imams of literature and news (79); He says: [From a simple swallow]

\section{You talked about the mouth of it, the} sweetener, a cheek and a hole, so the glory of the Lord. This is about Al-Waqidi tells

addressing some of the masculine qualities, Fajdodh Kvakeh apples, saliva net such as alcohol, saying(:From the complete)

Whoever turns the apples of your cheek with excuses

depicting the sweetness of his saliva as dew, because his sweetness was similar to the plant that contains yellow nectar, and he says: [From Majzo Al-Kamil]

And He permitted me to break a covenant, and I 


\section{sipped my dew}

And he has it elsewhere, by saying (from the abundance)

A book that only he could read, and he

broke his eyelids when he read it $^{(84)}$

\author{
I wrote to the beloved with a twinkling of \\ my limb, and he told me of his flowering \\ and paradise
}

And he said (from the fast)

\section{A window in all that governs the teeth of people and arrows ${ }^{(85)}$}
The judgments of your eyelids are in my vein, and as long as I have carried out the same

Wei g r poet in the sommelier sensuous specifications of ,from saying of Mdzu Waller ml

\author{
The Bjam Khosrvani \\ $T$.did not understand the statement of the \\ Ogma held my tongue ${ }^{(86)}$
}

O drearer with a eyelid, do not blame me if you rest, the magic of your eyes and my drunkenness

It is no doubt that the sommelier bars evocative, has much hesitation in St .Presentation of this stage ;As they flirted with him and mentioned his qualities. ${ }^{(87)}$ He said in good externa rack (of long)

\author{
Bleak of my lust and my mind going, \\ struck you with a broadcast ?I said: If the \\ companion $^{(88)}$
}

And when they saw me as an orphan ,they inherited me and said: You were of sound mind
It should be noted here, "I promised the physiological changes that occur to young people, and one of the most prominent topics that poets interact with, Ludo noticed in their poetry, not in terms of the abundance of their order; but in terms of their importance in the relationship between the master and the servant; Because these changes, and in particular (the beard), are an end sign (the suitability of the boy for pleasure). " (89) It is noted that the previous health war came in two directions: the first, the sensual, to describe the boy, while the second direction: was to describe his feelings and his inner self, the direction Sweetheart, these were Walsh's models. Shopping cart, enjoy a great deal of aesthetics E: the interesting meaning, a graceful and discreet word, and an image of sweet, warm, and tight emotion. Allen (90) is not only what is offered in the spinning of youth; but the consolation of the poets $\mathrm{g}$ The content of the aji differed according to the relationship of elegy and elegy. So it was a relationship between them hb, the texts would be a chariot full of feelings of pain and sadness, but the boy was just a servant who carries out the duties of his master, the poet organizing a poetic text in which he loses it. Services of Abdo Tire (91). Dalia comes under Smart's hair to lose her lover, enumerates her advantages and describes her grief 
over the loss, and said her condition in herself, a balance between the beauty of the soft cheek, the more attractive now Asi, and the sensual qualities of the other, and what resulted from the changing

Preserves the Covenant and takes care of the Dadi classed as toddler dresses pressed Dad white from the black people of the $\operatorname{cheek}^{(92)}$

In the same context, he says (From Al-Khafif)

\section{And how much you lost your navigation in excess,} and our face and yours remain one ${ }^{(93)}$ features, the texts became after the Welch Kart Pixa sadness And enveloped in black pain, mourning and mourning for the well and beauty of us Dor, saying: [Al-Raml]

\section{Hassan died cheek mm $\mathbf{n}$ was not \\ Vksah hair from sorrow on my her clothes had been left}

\author{
How much did you have \\ ravaged and waned, \\ and then all went away as you became \\ bearded
}

Ring of

The study concluded a number of the following results

1. Spinning with boys was not an invention of the poets of the Mamluk era, as historians attributed it to Abu Nawas, and his neighbors from the poets of wine and singing in the Abbasid era, who responded to civilization and civilization. The openness in their community.

2. It is noted that ghazal appears with the masculine in Walsh's presentation of the Mamluks. As we found it among most poets, they used to remember many boys and girls in their spinning, imitating hadiths and those born from poets.

3. Spinning with boys is one of the aspects that flourished in the Mamluk era, and now this phenomenon embodies immorality and immorality, and it is a moral dissolution in this era. The boys are full in the houses of palaces, taverns, and moneylenders for entertainment and entertainment, and poets kicked the age of wrestling, and they want to broadcast their salvation, photograph the boxes, paint the features of their simulation, in the poems did not reciprocate, Lord. Of partridge statements, and did not hesitate to use profanity, slander and rudeness.

4. Poets of the Mamluk era composed many poems and verses in spinning with boys and their camels. These poems were collected by mad writers and pious scholars, so courting the masculine was a general phenomenon at that time, and it was not limited to a group of poets only.

5. Singing the beauty of the youth, or flirting with the masculine, which occupied a large area of the era of the Mamluk ghazals, so do not exaggerate if we say that the woman reduced her share of the yarn, if the writers measured the beauty of the masculine sexy, and there are some literary texts of my short stories. In describing One Hundred Mleih) on flirting with boys, Shihab Hijazi singled out in his book (Road Arts), and spinning Baba completely masculine content. It's rare to see a poet or writer who has made no difference in this field.

6. The poet Alan Lqeeb is one of those poets who fought in the midst of this art, and in it they wrote what they suffered from opposition, or opposed to him tastes and the prevailing nudity. He had a clear emotional experience. But it is an honest emotional 
experience that challenges the friendship young people live in and learn from. Which inspired him a lot from Algmana show.

7. Flirting with children is nothing more than a tradition. It is a natural consequence of a bad moral and social situation. As a result of the civilizational deterioration of the Arab country, in the anomalous wave, the deviant behavior of the deer that prevailed in the first Abbasid era, had clear and influential repercussions in the saint providing these pressure prices.

8. I love this poet Thor. He was expressing a psychological tendency represented in his love for children, and the expression of this poetic love. Therefore, his flirting photos were the most masculine. A g, no, Bethlehem, C, where Moheen or A thousand surplus.

\section{Margins}

1. See: Ibn Manzur (p. 711 AH): San AlArab, part 6, article (ghazal)

2. See: Mustafa, Ibrahim, and others: The Pain of the Intermediate Ajam, p. 385.

3. See: Maalouf, Lewis: Al-Munajjid fi linguistics and scholarship, p. 550 / Article (Gazelle)

4. See: Al-Tanji, Dr. Muhammad: The Pain of the Persians detailed in the literature, $2 \mathrm{j}$ / p. 670.

5. See: Muhammad, Serageldin: Spinning in Arabic Poetry, p. 6.

6. See: Nassar, Nawwaf: The Literary Dictionary, p. 146.

7. See: Abd al-Nour, Jabour: The Pain of the Literary Ajam, p. 187.

8. See: Al-Tanji, Dr. Muhammad: The Detailed Dictionary of Literature, Part 2 / p. 670.

9. See: Dhaif, Dr. Shawky: A History of Arab Literature - The Second Abbasid Era, p. 443.

10. See: Salem, Mahmoud Rizk: Arabic literature from the Fatimid era to today, p. 74.
11. See: Al-Tanji, Dr. Muhammad: The Detailed Dictionary of Literature, Part 2 / p. 672.

12. See: Al-Dreesi, and Wafaa: Al-Ubaid and Boys in Islamic Culture, the Gender Approach, and p. 283.

13. See: Dhaif, Dr. Shawky: Emergence and Regeneration in Umayyad Poetry, p. Seen: Mahud, Jinan Khaled: Spinning with Masculine in Walsh Presentation of Andalusian Motives and Characteristics, p. 513.

14. See: Mahmoud, Jinan Khaled: Spinning with the masculine in Andalusian poetry, its motives and characteristics, pp. 513514.

15. See: Al-Fakhoury, Hanna: All in the History of Arabic Literature - Ancient Literature, vol.1 / p. 673.

16. See: Amin, Dr. Fawzi Muhammad: Literature of the First Mamluk Era - Issues of Society and Art, p. 357.

17. See: Al-Tanji, Dr. Muhammad: The pain of Ajam in detail for literature, $2 \mathrm{j} / \mathrm{p} .672$.

18. See: Al-Fadhel, Dr. Ahmed: History and Epochs of Arab Literature, p. 168.

19. Seen: Al-Wardi, Dr. Ali: The Legend of Sublime Literature, p. 71.

20. See: Al-Nuhi, Dr. Muhammad: Nafsiyat Abi Nawas, p. 72.

21. See: Himself, pp. 87-88.

22. See: Al-Wardi, Dr. Ali: The Legend of Semitic Literature, pp. 71-72.

23. See: Al-Hadara, Dr. Muhammad Mustafa: Arab Poetry Trends in the Second Hijri Century, pp. 220-221.

24. See: Al-Nuhi, Dr. Muhammad: Nafsiyat Abi Nawas, pp. 89-90.

25. See: Shakaa, Mustafa: Andalusian literature, its arts and themes, p. 53.

26. See: De Wafa F, Dr. Shawky: A History of Arab Literature - The First Abbasid Era, p. 384.

27. Al-Salam, Dr. Muhammad Zaghloul: Literature in the Ayyubid Era, p. 323. 
28. See: Dhaif, Dr. Shawky: A History of Arab Literature - The First Abbasid Era, p. 370 .

29. See: himself, p. 71.

30. See: Mahud, Jinan Khaled: Ghazl by the masculine in the presentation and the Walsh Presentation of Andalusian motives and characteristics, p. 515.

31. See: Nafas H, p. 515.

32. See: Al-Fakhoury, Hanna: Al-Mujees in Arabic Literature and its History, Part 2 / p. 304.

33. See: Rashid, Dr. Nazim: In the Literature of Late Ages, p. 32.

34. See: Al-Dreesi, Slaves and Boys in Islamic Culture, Gender Approach, p. 295.

35. See: Al-Rubaie, Dr. Muhammad Shaker: Walsh Presentation in the Levant in the Middle Ages from $656 \mathrm{AH}$ to $1213 \mathrm{AH}, \mathrm{p}$. 168.

36. See: Abu Ali, Dr. Nabil Khaled: Arabic literature between the Mamluk and Ottoman eras, vol.1 / p. 134.

37. See: himself, vol.1 / p. 134.

38. See: Al-Hussein, Dr. Qusai: Arabic Literature in the Mamluk and Ottoman Era, p. 292.

39. See: Amin, Dr. Bakri Sheikh: Reviews in Mamluk and Ottoman Poetry, p. 125.

40. See: Al-Ayoubi, Dr. Yassin: Perspectives of Arabic Poetry in the Mamluk Era, p. 154.

41. See: Pasha, Dr. Omar Musa: Literature in the Levant, the era of the Zankites, the Ayyubids, and the Mamluks, p. 579.

42. See: Abu Zaid, Dr. Sami Yusuf: The Literature of the Countries of the Zankites, the Ayyubids, and the Successive Mamluks, p. 60.

43. See: Muhammad, Dr. Mahmoud Salem: Literature of the Land of Succession Mamluk State, p. 85.

44. See: Youssef, Dr. Khaled Ibrahim: Arabic Poetry in the Days of the Mamluks and Their Time, p. 420.
45. See: Amin, Dr. Fawzi Muhammad: Literature of the First Mamluk Era - Issues of Society and Art, p. 358.

46. See: Youssef, Dr. Khaled Ibrahim: Arabic Poetry in the Days of the Mamluks and the Days of His Reign with the Sultan, pp. 420-421.

47. Abdel-Rahim, Dr. Raed Mustafa Hassan: The Art of Lamentation in Arabic Poetry in the First Mamluk Era, p. 274.

48. See: Yusef, Dr. Khaled Ibrahim: Arabic Poetry in the Days of the Mamluks and Their Time, p. 421.

49. See: Al-Salam, Dr. Muhammad Zaghloul: Literature in the Ayyubid Era, p. 70. See: Hussein, Muhammad Kamel: Studies in Poetry in the Ayyubid Era, p. 136.

50. See: Ibn al-Naqib Alf Lisi (verse $687 \mathrm{AH}$ ): Al-Diwan, p. 7.

51. See: Ibn Shakir, ULC v B (v 764 e): Too death, c $1 /$ p. 314.

52. See: Same, Vol.1 / p. 314.

53. See: Al-Zarkali, Khair El-Din: Al-Alam, part 2 / p. 192.

54. See: Ibn al-Naqib Alef al-Lisi: Al-Diwan, p. 5.

55. See: himself, pp. 10-11.

56. See: Ibn Tajir Bardi (No. 874 AH): The Shining Stars in the Kings of Egypt and Cairo, 7 J / A. 317.

57. See: Ibn Taghri Bardi: The Bright Stars in the Kings of Egypt and Cairo, Part 7 / p. 317- Seen: Goth, Jalaluddin (d.911 AH): Omar Lecture in Egypt and Cairo News, $1 \mathrm{j}$ / p. 464.

58. See: Khalifa, Dr. Ahmed: The Beautiful Young Man in Love and Spinning, p.57.

59. See: Al-Ayoubi, Yassin's solution Safi alDin, c, p. 183.

60. See: Youssef, Dr. Khaled Ibrahim: Arabic Poetry in the Days of the Mamluks and Their Time, p. 421.

61. See: Hussein, Ali Safi: Ibn Daqiq Al-Eid, His Life and His Divan, p. 41.

62. See: Al-Hussein, Dr. Qusai: Arabic Literature in the Mamluk and Ottoman 
Era, p. 292. See: Al-Ayoubi, Dr. Yassin: Perspectives of Arabic Poetry in the Mamluk Era, p. 154.

63. See: Al-Ayoubi, Dr. Yassin: Perspectives of Arabic Poetry in the Mamluk Era, p. 154.

64. See: Ibn al-Naqib Alef al-Lisi: Diwan, p. 26-27.

65. Same thing p. 191.

66. Same thing p. 180.

67. Same, pp. 86-87.

68. Same thing p. 71.

69. See: Al-Tanji, Muhammad: Literary Currents in the Mughal March, p. 414.

70. Ibn al-Naqeeb Alf Lisi: Diwan p. 103.

71. Same, pp. 134-135.

72. Same thing p. 155. See also: himself, p. 146.

73. Same thing p. 135. See also: himself, p. 141.

74. See: Al-Kafrawy, Muhammad AbdelAziz: Walsh's Presentation to the Arabs between Stagnation and Development, p. 99.

75. Ibn al-Naqib Alf-Lisi: Diwan, p. 104.

76. Same thing p. 138.

77. Same thing p. 79.

78. See: Al-Zarkali, Khair El-Din: Al-Alam, vol. 6 / p. 311.

79. See: ibid., Part 7 / p. 144.

80. Ibn Al-Naqeeb Alf Lisi: Diwan, pp. 89-90.

81. Same thing p. 72.

82. See: Al-Saeed, Muhammad Majid: The Show of Walsh in the Shadows of Ubaid Bani, p. 153.

83. Ibn al-Naqib Alf-Lisi: Diwan p. 86.

84. Same thing p. 196.

85. Same thing p. 178.

86. Same, p. 190.

87. See: Al-Rubaie, Dr. Muhammad Shaker: Walsh Presentation in the Levant in the Middle Ages from 656 AH to 1213 AH, p. 172.

88. Ibn Al-Now on the authority of Al-Aif BC. Al-Lisi: Diwan p. 70. See: himself, p. 170.
89. Al-Dreesi, Wafaa: Slaves and Boys in Islamic Culture, The Gender Approach, p. 295.

90. See: Youssef, Dr. Khaled Ibrahim: Walsh showed the Arab and Mamluk days of their families with Sultan, p. 424.

91. See: Al-Dreesi and Al-Wafa: Al-Mawari and Al-Banin in Islamic Culture, the Gender Approach, p. 298.

92. Ibn Al-Now on the authority of Al-Awf BC. Al-Lisi: Diwan p. 97.

93. Same thing p. 89.

\section{References}

[1] Ibn Yaghri Bardi (d. 874 AH): Allen Jum Wells Cairo to the kings of Egypt and Cairo. She gave and commented on him: Muhammad Hussein Shams al-Din, Beirut - Lebanon, Dar al-Kutub al-Ilmiyya, 1st Edition, 1413/1992.

[2] Ibn Shaker Al-Ketbi (d.764 AH): Jada Jada, edited by: Ali Muhammad Moawad and Adel Ahmad Abd- Al-Mawjid, Beirut - Lebanon: Dar Al-Kutub Al-Ilmiyya, 1st Edition, 1421/2000

[3] Ibn Manzur (d. 711 AH): San Arab, for investigation by: Amin Muhammad Abd al-Wahhab, Muhammad Sadiq al-Ubaidi, Beirut - Lebanon: House of Revival of Arab Heritage, 1st Edition, 2010.

[4] Ibn Alan, to the captain of a thousand BC. Al-Lisi M. (d.687 A.H.): The collection, investigation and study office: Dr. Abbas Hani Al-Jarakh, Damascus - Syria: July for printing, publishing and distribution, 1st Edition, 2012 AD.

[5] Abu Zaid, Dr. Sami Yusef: The Literature of the Father of Al-Zanki, Al-Ayyubi and the Successive Mamluk, Amman - Jordan: Dar Masirah for Publishing, Distribution and Printing, 1st Edition, 1433 AH / 2012 AD.

[6] Abu Ali, Dr. Nabil Khaled: Arabic Literature between the Mamluk and Ottoman Era, Gaza - Palestine: Dar AlMiqdad for Printing, No. T, 2007 AD. 
[7] Amin, Dr. Bakri Sheikh: Reviews of Mamluk and Ottoman Poetry, Beirut Lebanon, House of Science for the Millions, No. T, Dr.

[8] Amin, Dr. Fawzi Muhammad: Literature of the First Mamluk Era - Issues of Society and Art, Alexandria - Egypt: University Knowledge House, No. T, 1993 AD.

[9] Al-Ayoubi d. Yassen:

[10] Perspectives of Arabic Poetry in the Mamluk Era, Tripoli - Lebanon: House Gross Press, 1st Edition, 1415/1995.

[11] $\square$ Solution Safi Al-Din J, Beirut Lebanon: The Lebanese House Book, 1st Edition, 1971.

[12] Pasha D. Amr Moussa: Literature in the Levant, Al-Zangi, Ayyubid and Mamluk, Beirut - Lebanon: Damascus - Syria: Dar Al-Fikr for Printing, Distribution and Publishing, 1st Edition, 1409/1989.

[13] Al-Tanji Dr. Muhammad:

[14] Literary Currents in the Period of Mongolian Progress, Damascus - Syria: Tlass House for Studies, Translation and Publishing, Issue T, 1987 AD.

[15] Pain Ajam Detailed Literature, Beirut Lebanon: The National Scientific Library, second floor, 1419/1999.

[16] Hussein Ali Safi: Ibn Daqiq Al-Eid, his life and office, Cairo - Egypt: Dar Al Maaref No. T, 1960 AD.

[17] Madhout Sen, Dr. Qusai: Arabic Literature in the Mamluk and Ottoman Era, Tripoli Lebanon: The Modern Foundation for Book Publishers, First Edition, 2011 AD.

[18] Hussein, Muhammad Kamel: Studies in Poetry in the Ayyubid Era, Cairo - Egypt: Al-Hindawi Foundation for Publishing and Distribution, No. T, 2017 AD.

[19] Khalifa, Dr. Ahmed: Cheb Zarif, Poet of Love and Spinning, Cairo - Egypt: Literature Library, No. T, 2003 AD.

[20] Al-Draissi, Wafaa: Slaves and Children in Islamic Culture, a Gender Approach, Rabat - Morocco: Believers Without
Borders for Publishing and Distribution, First Edition, 2016.

[21] Al-Rubaie, Dr. Muhammad Shaker: Poetry in the Levant in the Middle Ages from the year $656 \mathrm{AH}$ to $1213 \mathrm{AH}$, Amman Jordan: Dar Al-Radwan for Publishing and Distribution 1st Edition, 1433 AH / 2012 AD.

[22] Rashid, Dr. Nazem: In Literature of Later Times, Mosul, Iraq - Bassam, i, 1406 Library Publications / 1985.

[23] Wells kicking me, father of the good Yen: The Flags, Beirut - Lebanon: House of Science for the Millions, to A.t, DT

[24] Saeed Muhammad Majid: Walsh Presentation in the Light of Abnaa AlUbaid, Najaf, Iraq - Numan Printing Press until 1972.

[25] Salam Dr. Muhammad Zaghloul: Literature in the Ayyubid Era, Alexandria - Egypt: The Institute of Knowledge, No. T, 1990 AD.

[26] Salem Mahmoud Rizk Arabic literature from the Fatimid era to the present day, Alexandria - Egypt: Salah al-Din Press, 1st Edition, 1357 AH / 1938.

[27] Alice Aouti, Jalal Al-Din (pp. 9-11 AH): An Omriya lecture on the news of Egypt and Cairo, Margins by Khalil Mansour, Beirut - Lebanon: Dar Al-Kutub AlUlama, 1st Edition, 1418/1997.

[28] Shakaa, Mustafa: Andalusian Literature, Art and Its Subjects, Beirut - Lebanon: Dar Al-Alam Al-Malayn, 4th Edition, 1979 AD.

[29] Guest of Honor, Dr. Shawky:

[30] History of Arab Literature - The First Abbasid Era, Cairo - Egypt: Dar Al Maaref, Sixth Edition, Dr.

[31] History of Arab Literature - The Second Abbasid Era, Cairo - Egypt: Dar Al Maaref, Sixth Edition, 1986 AD.

[32] Walt developed a new development at Walsh's Umayyad Show, Cairo - Egypt: House of Knowledge, 2nd floor, DT 
[33] Abdul Rahim d. Raed Mustafa Hassan: The Art of Self-Compassion in Arabic Poetry in the First Mamluk Era, Amman Jordan: Dar Al-Razi for Printing, Publishing and Distribution, Edition 1, 1424/2003.

[34] Abdel Nour, Jabour: Literary Ajam Pain, Beirut - Lebanon: House of Knowledge for the Millions, to A.T., Dr.

[35] Fakhoury Hanna

[36] The Whole in the History of Arabic Literature - Ancient Literature, Qom Iran: Relatives Publications, Third Edition, $1427 \mathrm{AH}$.

[37] The Brief of Arab Literature and Its History, Beirut - Lebanon: Dar Al-Jeel, 1st Edition, 1985 AD.

[38] Honorable Dr. Ahmed: History and era of Arab literature, Beirut - Lebanon: Lebanese Thought House, 1st Edition, 2003 AD.

[39] Al-Kafrawy, Muhammad Abdel Aziz: Walsh Presentation between Arab Recession and Development, Cairo Egypt: The Egyptian Renaissance Library in Fagala, 2, 1958.

[40] Mahmoud, Jinan Khaled: Al-Ghazl with the masculine in Andalusian poetry, its motives and characteristics, Baghdad Iraq: Quarterly Journal, University of Baghdad - College of Islamic Sciences, without publication, Dr.

[41] Muhammad, Serageldin: Spinning in Arabic Poetry, Beirut - Lebanon: University Salaries House, No.

[42] Muhammad, Dr. Mahmoud Salem: father of literature and successor - state-owned, Abu Dhabi - United Arab Emirates: Abu Dhabi Tourism and Culture Council, National Library, 1st Edition, 1433 AH / 2012 AD.

[43] Mustafa, Ibrahim and others: The Pain of Ajam Al-Wasit, Beirut - Lebanon: House of Revival of the Arab Heritage, 1st Edition, 1429/2008.
[44] Maalouf, Lewis: Al-Munajjid in Language and Media, Beirut - Lebanon: Dar AlMashriq, 29th Edition, 2008 AD.

[45] Nassar, Nawwaf: Literary Pain of the Ajam, Amman - Jordan: Word House for Publishing and Distribution, 1st Edition, 2007.

[46] Al-Noahi, Dr. Muhammad: Nafsiyat Abu Nawas, Cairo - Egypt: Al-Khanji Library, Second Edition, 1970 AD.

[47] Civilization, Dr. Muhammad Mustafa: Trends in Arabic Poetry in the Second Hijri Century, Cairo - Egypt: Dar Al Maarif, No. T, 1963 AD.

[48] Pink, Dr. Ali: The Legend of Semitic Literature, Qom - Iran: Al-Haidari Library Publications, First Edition, 2000 AD.

[49] Joseph, Dr. Khaled Ibrahim: Walsh presented the Arab days of the Mamluk and their families with Sultan, Beirut Lebanon: Dar Al-Nahda Al-Arabiya, 1st Edition, 2003. 